\title{
Effect of dietary calcium level on mineral and trace element utilization from a rapeseed (Brassica napus L.) diet fed to ileum-fistulated pigs
}

\author{
BY TORBEN LARSEN \\ National Institute of Animal Science, Animal Physiology and Biochemistry, Foulum, PO Box 39, \\ 8830 Tjele, Denmark
}

AND BRITTMARIE SANDSTRÖM

Research Department of Human Nutrition, Royal Veterinary and Agricultural University, Rolighedsvej 25, DK-1958 Frederiksberg C, Denmark

(Received 17 July 1991 - Accepted 21 January 1992)

\begin{abstract}
The bioavailability of intrinsic minerals in rapeseed (Brassica napus L.) meal was studied in growing, fistulated pigs. Furthermore, the effect on mineral availability of an extrinsic Ca supply to this diet, high in phytate, was observed. Comparisons between small intestinal and total gastrointestinal absorption were accomplished for minerals and other dietary components. $\mathbf{N}$ retention increased as the dietary $\mathbf{C a}$ intake increased, but dropped, in general significantly, throughout the experimental period, indicating that factors other than protein were limiting for growth. The highest dietary Ca level increased the absorption and retention of $\mathrm{Ca}$ and $\mathrm{Mg}$. In contrast, addition of $\mathrm{CaCO}_{3}$ did not influence the apparent absorption and retention of $\mathrm{P}, \mathrm{Fe}, \mathrm{Zn}, \mathrm{Cu}$ and $\mathrm{Mn}$. The majority of observed blood variables was not affected by the Ca content of the diet. Zn status-related variables were, however, thoroughly depressed by duration of the experiment and it seems probable that the amount of absorbed $\mathrm{Zn}$ was a factor limiting growth. Total gastrointestinal balances showed a $\mathrm{Zn}$ retention of $4.7 \mathrm{mg} / \mathrm{d}$, which accounted for $13.6 \%$ of that ingested. This low absorption of $\mathrm{Zn}$ may have been due to the high intrinsic content of phytate. Apparent absorption of organic matter, ash, $\mathbf{N}$ and $\mathbf{S}$ was significantly greater calculated from faecal contents than from ileal contents, indicating a disappearance of material in the caecum-colon section of the gastrointestinal tract. The minerals which were studied showed the opposite pattern: apparent small intestinal absorption was larger than total intestinal absorption, suggesting that the caecal-colon region takes part in mineral turnover.
\end{abstract}

Rapeseed meal: Mineral bioavailability: Calcium: Pig

Rapeseed (Brassica napus L.) meal is widely used as a protein source in animal nutrition. Besides having a well-balanced amino acid composition, the seeds also contain considerable amounts of minerals in comparison to most other feedstuffs (Just et al. 1983). Little attention has so far been given to the intrinsic minerals of feed sources, and under practical feeding conditions minerals are often added to the diets, almost ignoring the intrinsic mineral content.

It has long been recognized that the availability of minerals in animal feed sources can be low. O'Dell \& Savage (1957) noted that $\mathrm{Zn}$ from plant proteins was less available to chickens than $\mathrm{Zn}$ from animal proteins. Similar observations have been confirmed with swine (Smith et al. 1962). The low availability is thought to be due to the presence of phytate and other complexing agents in plant food sources. Addition of phytate to a casein-gelatine diet for chickens produced the same symptoms of $\mathrm{Zn}$ deficiency as found 
with a soyabean-protein diet (O'Dell \& Savage, 1960). Most plant products are low in Ca, necessitating the addition of $\mathrm{Ca}$ to diets of fast-growing animals. $\mathrm{Ca}$ has, however, been suspected of impairing $\mathrm{Zn}$ availability in pigs (Tucker \& Salmon, 1955; Luecke et al. 1956, 1957). A Ca-phytate-Zn interrelationship was suggested by Oberleas et al. (1962) and later clearly demonstrated by O'Dell et al. (1964), in a regular three-factor experimental design in chickens.

More recently, the phytate: Zn molar ratio (Davies \& Olpin, 1979; Morris \& Ellis 1980) and the phytate-Ca:Zn ratio (Davies et al. 1985; Fordyce et al. 1987) have been suggested as indices for dietary $\mathrm{Zn}$ availability. The formation of $\mathrm{Zn}-\mathrm{Ca}-$ phytate complexes or other $\mathrm{Zn}$-phytate complexes in the upper gastrointestinal tract of simple-stomached animals is believed to be a major mechanism by which phytate and $\mathrm{Ca}$ reduce dietary $\mathrm{Zn}$ bioavailability.

Rapeseed is high in intrinsic phytate, the primary phosphate reserve in most plant seeds. Of the rapeseed meal-phosphate more than half is contained in the phytate molecule. Furthermore, the temperature used for oil extraction inactivates the natural content of phytase (EC 3.1.3.26). These circumstances suggest a poor availability of phosphorus to the animal, and a potential inhibition of the absorption of other minerals.

The first aim of the present study was to determine the availability to the pig of the intrinsic $\mathrm{Ca}, \mathrm{P}, \mathrm{Mg}, \mathrm{Fe}, \mathrm{Zn}, \mathrm{Cu}$ and $\mathrm{Mn}$ contained in rapeseed meal. The second aim was to examine the possible effects on mineral absorption and retention of externally supplied $\mathrm{Ca}$ to a diet high in phytate.

A third aim of the study was to compare small intestinal absorption and total gastrointestinal absorption of dietary components. The hypothesis was that fermentation in the hind gut could improve absorption of minerals. Microbial action could open up complex structures, thereby releasing minerals from digesta or generating ligands strong enough to release minerals from insoluble mineral-phytate complexes and expose them to intestinal solution. Providing these released or ligated minerals could be absorbed, the colon could play an active role in mineral utilization.

To elucidate these objectives we used ileum-fistulated pigs as experimental animals over a 1-month feeding period. Separate balances were performed on small intestinal digesta and faeces. Blood samples were drawn throughout the experiment and analysed to indicate mineral status, and livers were analysed as a criterion of mineral deposition.

\section{MATERIALS AND METHODS}

\section{Animals}

Twelve female pigs of approximately $30 \mathrm{~kg}$ body-weight, three from each of four litters, were fitted with simple ' $T$ ' cannulas in the ileum about $100-200 \mathrm{~mm}$ cranial to the ileocaecal junction. The design of the cannula was different from that of a common ' $T$ ' cannula. An intact tube fitted tightly to the inner wall of the small intestine, only permitting digesta to pass through the tube. By placing another tube of an outer diameter marginally smaller than the inner diameter of the intact tube, through the exterior opening of the ' $T$ ' cannula, it was possible to collect total outflow. Furthermore, the outlet tube could be closed to ensure normal passage through the intestine. With this technique the use of markers could be avoided.

The animals were placed in stainless-steel metabolism cages throughout the entire trial.

\section{Diets}

The composition of the experimental diets is given in Table $1 . \mathrm{CaCO}_{3}(9 \cdot 20$ and $18 \cdot 50 \mathrm{~g}$ respectively) was added to diets 2 and 3 . Besides $\mathrm{CaCO}_{3}, \mathrm{NaCl}$ was the only mineral added 
Table 1. Composition of the experimental diets $(\mathrm{g} / \mathrm{kg}$ diet $)$

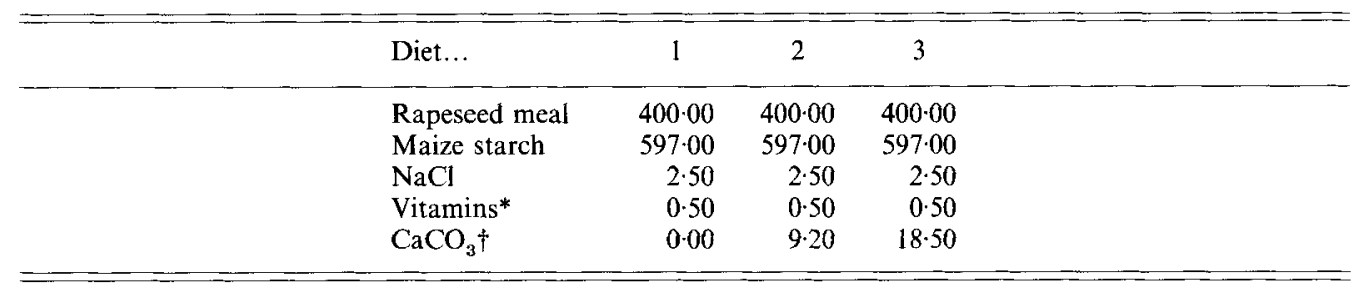

* Vitamins $(\mathrm{mg} / \mathrm{kg}$ feed): retinol palmitate $2 \cdot 2$, ergocalciferol $0 \cdot 01$, dextocopherylsuccinate 40 , thiamin hydrochloride 2, riboflavine 5 , pyridoxine hydrochloride 3 , nicotinamide 25 , Ca-pantothenate 15 , biotin $0 \cdot 2$, cyanocobalamin 0.02 , phytomenadione 2 , pteroylmonoglutamic acid 0.6 .

$\uparrow$ Analytical grade; Merck art 2066.

Table 2. Chemical composition of the experimental diets (/kg dry matter)

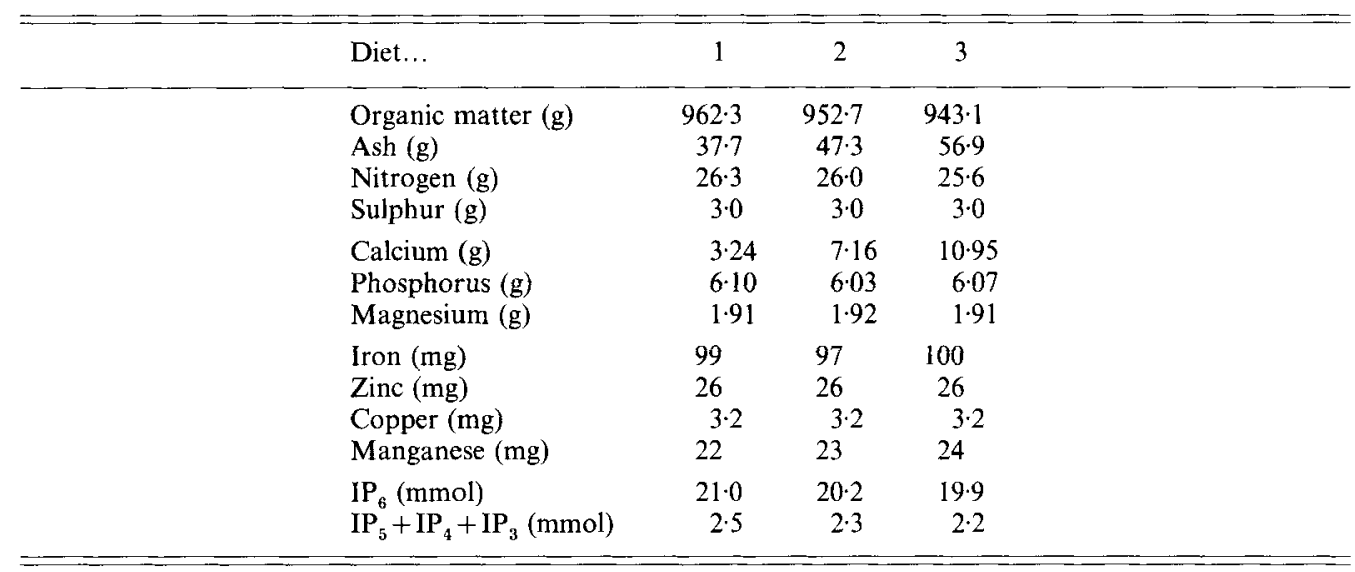

$\mathrm{IP}_{3}-\mathrm{IP}_{6}$, inositol phosphates containing three to six phosphate groups per inositol residue.

to the diets. Other dietary minerals were exclusively of intrinsic nature. The contents of nutrients and phytic acid are given in Table 2. The animals were fed twice daily, at 08.00 and 15.00 hours, in equal amounts. The dry diets were mixed with water $(1: 2 \cdot 5, \mathrm{w} / \mathrm{v})$ just before feeding. Only demineralized water (Elgastat UHP system; Elga Ltd., High Wycombe, UK) of negligible mineral content was used. The feeding level was restricted to avoid feed residues. Daily levels were $1400 \mathrm{~g}$ air-dry feed when the pigs weighed approximately $30 \mathrm{~kg}$ and increased to $1600 \mathrm{~g}$ at the end of the $32 \mathrm{~d}$ trial, when the pigs weighed $40 \mathrm{~kg}$.

\section{Collecting procedures}

Digesta and faeces. Total collection of ileal digesta was performed for $24 \mathrm{~h}$ on days 15,18 and 29 by diverting the contents from the fistula through a plastic tube to an ice-cooled container. The digesta was removed and deep-frozen at appropriate intervals. Total faeces and urine collections were performed twice, during days 8-13 and again during days 22-27. Faeces was collected directly in plastic bags taped to the backs of the animals, while urine was collected via a catheter to a container with preserving acid. The collected digesta and faeces were freeze-dried, manually disintegrated in a porcelain pestle and mortar and representative samples were taken for analyses. To improve the precision in the balance 
calculations, the feed level was kept constant for $2 \mathrm{~d}$ before ileal and faecal collections and during the total collection period.

Blood. Fresh blood samples were withdrawn before the morning feeding using heparinized needles on days 4, 18 and 32, and collected in acid-washed, heparinized glass tubes.

Livers. The livers were removed after slaughter and representative samples, twenty per liver, were obtained using a borosilicate cylinder, and stored at $-20^{\circ}$ until they were freeze-dried.

\section{Chemical analyses}

Representative samples of diets, digesta, faeces and urine were analysed for $\mathrm{N}$ (automatic Kjeldahl-procedure), elementary S (Nes, 1979) and ash. Determination of $\mathrm{Ca}, \mathrm{Mg}, \mathrm{Fe}, \mathrm{Zn}$, $\mathrm{Cu}$ and $\mathrm{Mn}$ were performed by atomic absorption spectrophotometry (PU $9400 \mathrm{X}$; Philips Scientific). Calibration of measurements was performed on commercial standards (Tritisol; Merck). Relative standard deviation for the determination ranged within $0.4(\mathrm{Ca})$ and 1.3 $(\mathrm{Fe}) \%(n 60)$. Chloride solutions of the respective metals (analytical grade) were used as independently-manufactured controls. $\mathrm{P}$ was analysed colorimetrically by the vanadomolybdate procedure (Stuffins, 1967). Before mineral analyses the samples (in duplicate) were dry-ashed in silica crucibles at $525^{\circ}$ for $6 \mathrm{~h}$. The ash was dissolved in hot dilute $\mathrm{HCl}-\mathrm{HNO}_{3}$ (analytical grade and Suprapur respectively).

The blood samples were wet-ashed in $\mathrm{HNO}_{3}-\mathrm{H}_{2} \mathrm{O}_{2}-\mathrm{HClO}_{4}(2: 1: 1$, by vol. $)$ exposed to increasing temperatures.

Haemoglobin was measured by the cyanmethaemoglobin method (Boehringer Mannheim $\mathrm{GmbH}$ ). Measurements of total alkaline phosphatase (EC 3.1.3.1) activity in blood plasma were performed as described by Bowers \& McComb (1975).

Phytate and its degradation products were determined by the high-performance liquid chromatographic method as described by Sandberg \& Ahderinne (1986).

\section{Statistical analysis}

The three experimental diets were randomized among the three litter-mates. This procedure was repeated fourfold, litters thus representing statistical blocks, separated in time. One pig had to be discarded due to a feeding mistake. The average value for the three $24 \mathrm{~h}$ digesta collections from each pig on a particular diet was considered as one replicate, and the average value for the faeces and urine from the two $5 \mathrm{~d}$ balances was treated likewise.

Results are presented in absolute values; standard errors are of statistical analysis, e.g. excluding effects of litters and dietary treatment. Statistical analysis was done using the SAS Institute Inc. (1985) system. Analyses of variance were performed with the general linear model (GLM) and ANOVA when balanced. Differences between parameters were estimated by the least significant difference (LSD) test.

\section{RESULTS}

\section{Feed intake, $N$ balance and growth}

Average daily feed intake during ileal and faecal collections was 1547 and $1520 \mathrm{~g}$ respectively on an air-dry basis. Values for intake, absorption and retention of organic matter, ash, $\mathbf{N}$ and $\mathrm{S}$, presented on a dry matter basis, are shown in Table 3.

Dietary intakes of organic matter and ash were influenced by the addition of $\mathrm{CaCO}_{3}$. The digestion of organic matter expressed in absolute amounts varied as a consequence, but the relative ileal $(0 \cdot 84)$ and faecal $(0.89)$ digestibilities were not affected by the dietary treatments.

The ash content of the diet increased by approximately $50 \%$ from the unsupplemented 


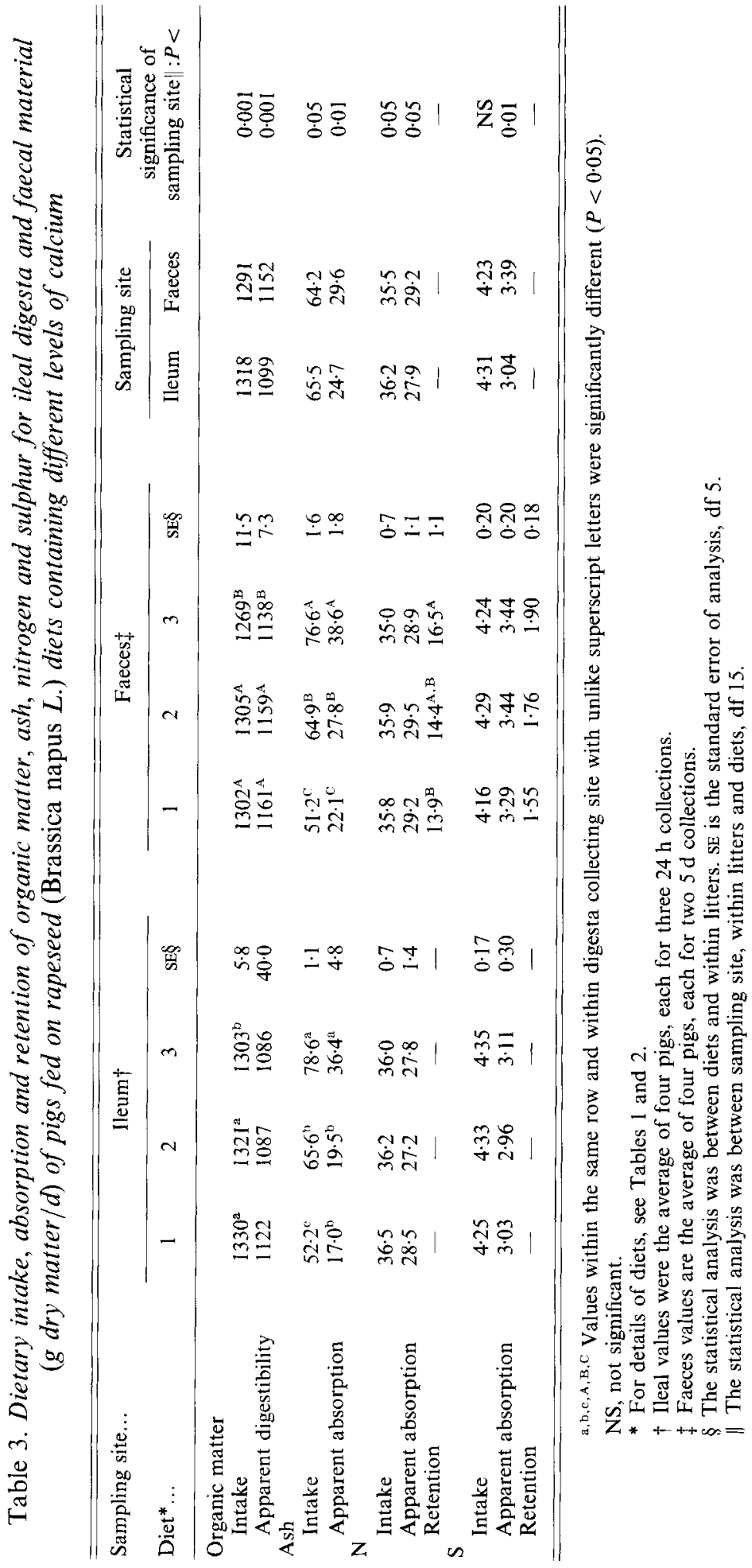


T. LARSEN AND B. SANDSTRÖM

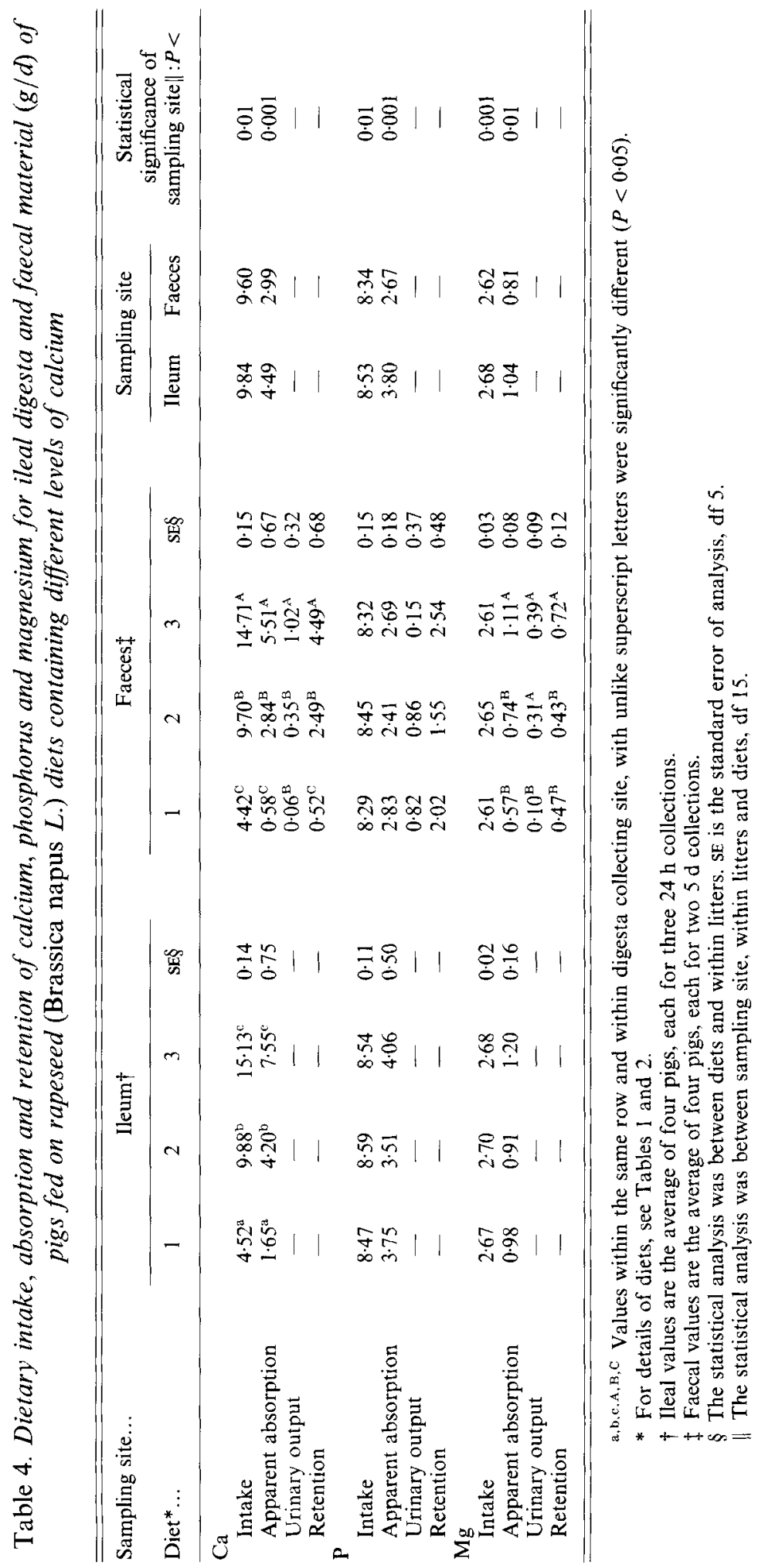


CALCIUM AND BIOAVAILABILITY OF RAPESEED MINERALS

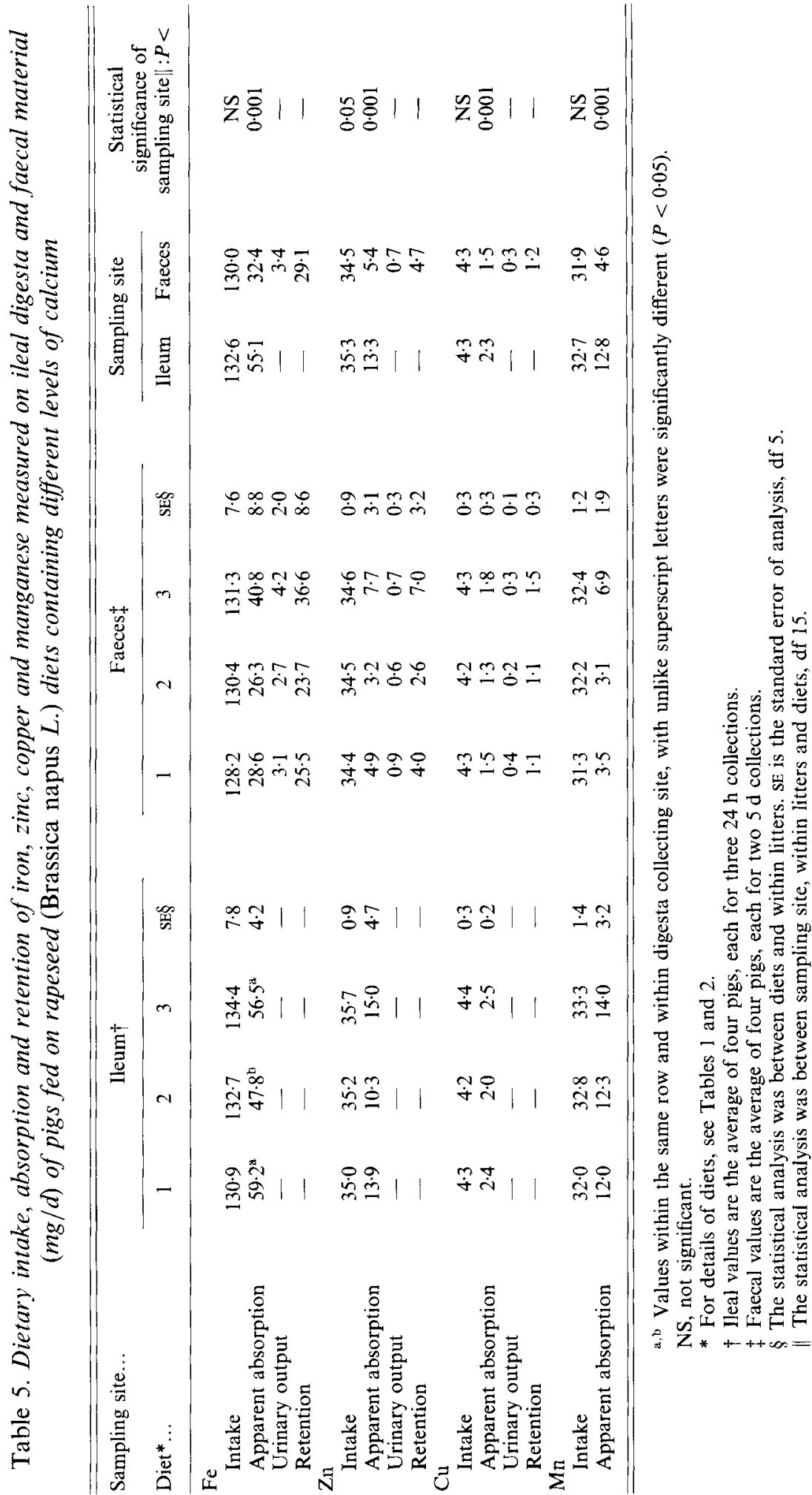


Table 6. The effect of the duration of the experiment on blood variables (mmol/l) of pigs fed on rapeseed (Brassica napus $L$.) diet containing different levels of calcium* ${ }^{* \dagger}$

(Mean values for eleven observations)

\begin{tabular}{|c|c|c|c|c|}
\hline $\begin{array}{l}\text { Day of sampling... } \\
\text { Blood variable }\end{array}$ & 4 & 18 & 32 & SE $\ddagger$ \\
\hline \multicolumn{5}{|l|}{$\mathrm{Ca}$} \\
\hline Whole blood & 1.56 & 1.51 & 1.57 & $0 \cdot 13$ \\
\hline Plasma & $2 \cdot 36$ & $2 \cdot 33$ & $2 \cdot 45$ & $0 \cdot 15$ \\
\hline \multicolumn{5}{|l|}{$P$} \\
\hline Whole blood & $15.8^{b}$ & $16 \cdot 9^{\mathrm{ab}}$ & $17 \cdot 2^{\mathrm{a}}$ & $1 \cdot 3$ \\
\hline Plasma & $3 \cdot 8^{\mathrm{a}}$ & $4 \cdot 2^{b}$ & $4 \cdot 2^{\mathrm{b}}$ & 0.4 \\
\hline \multicolumn{5}{|l|}{$\mathrm{Mg}$} \\
\hline Whole blood & $2 \cdot 09^{a}$ & $2 \cdot 12^{\mathrm{a}}$ & $2 \cdot 27^{\mathrm{b}}$ & $0 \cdot 13$ \\
\hline Plasina & $0.70^{\mathrm{a}}$ & $0.85^{\mathrm{b}}$ & $0.94^{\mathrm{c}}$ & 0.07 \\
\hline \multicolumn{5}{|l|}{$\mathrm{Cu}$} \\
\hline Whole blood & 0.023 & $0 \cdot 023$ & 0.024 & 0.002 \\
\hline Plasma & 0.019 & 0.017 & 0.018 & 0.003 \\
\hline \multicolumn{5}{|l|}{$\mathrm{Fe}$} \\
\hline Whole blood & $69 \cdot 8$ & $73 \cdot 6$ & $72 \cdot 2$ & $5 \cdot 7$ \\
\hline Haemoglobin $(\mathrm{g} / \mathrm{l})$ & $67 \cdot 2$ & $70 \cdot 3$ & $72 \cdot 9$ & $6 \cdot 5$ \\
\hline
\end{tabular}

a,b,e Values within the same variable with unlike superscript letters were significantly different $(P<0.05)$.

* For details of diets, see Table 1.

$\dagger$ The level of dietary $\mathrm{Ca}$ did not significantly affect blood variables measured.

\$ Standard error of analysis between blood sampling, within litters; df 27.

to the most highly supplemented diet. The apparent absorption of ash, on the other hand, tended to increase by a factor of two, both at the ileal and the faecal level, thereby revealing significant differences in absorption between treatments.

$\mathrm{N}$ intake was close to $36 \mathrm{~g} / \mathrm{d}$ for both ileal and total balances. The absorption of $\mathrm{N}$ was not influenced by the dietary treatments, neither at the ileal nor the faecal sampling site. However, urinary excretion differed; this resulted in increasing retention of $\mathrm{N}$ with increasing Ca supply $(P<0 \cdot 05)$.

$\mathrm{S}$ balance followed a similar pattern to that of $\mathrm{N}$ as regards intake, absorption, and retention and also within the sampling site. Retention tended to increase $(P<0 \cdot 10)$ as dietary $\mathrm{Ca}$ increased in the feed.

The daily weight gain of the animals was only moderate; with an average growth rate of $261 \mathrm{~g} / \mathrm{d}$. A significant difference $(P<0.01)$ between the diets was observed with 232,325 , and $241 \mathrm{~g} / \mathrm{d}$ for diets 1,2 and 3 respectively.

\section{Absorption and retention of minerals}

$\mathrm{Ca}$. The results for apparent absorption and retention of macrominerals are presented in Table 4. For the non-supplemented diet absorption in the small intestine was $37 \%$ $(1.65 \mathrm{~g} / \mathrm{d})$ and the total intestinal absorption was $13 \%(0.58 \mathrm{~g} / \mathrm{d})$. Increasing levels of $\mathrm{Ca}$ intake from the added $\mathrm{CaCO}_{3}$ resulted in an increased fractional as well as absolute absorption. Urinary excretion of $\mathrm{Ca}$ was directly proportional to absorbed $\mathrm{Ca}$, but the net retention of $\mathrm{Ca}$ was highest, $4.5 \mathrm{~g} / \mathrm{d}$, at the highest dietary $\mathrm{Ca}$ level.

$P$. P intake was not influenced by dietary composition. There was no significant effect of dietary $C a$ level on $P$ metabolism. Small intestinal absorption of $P$ was $3 \cdot 5-4.0 \mathrm{~g} / \mathrm{d}$, corresponding to, on average, $44 \%$ of intake. Apparent total intestinal absorption was $2 \cdot 4-2 \cdot 8 \mathrm{~g} / \mathrm{d}(32 \%$ of intake). Daily retention of $\mathrm{P}$ on the average amounted to $2.1 \mathrm{~g}$. 


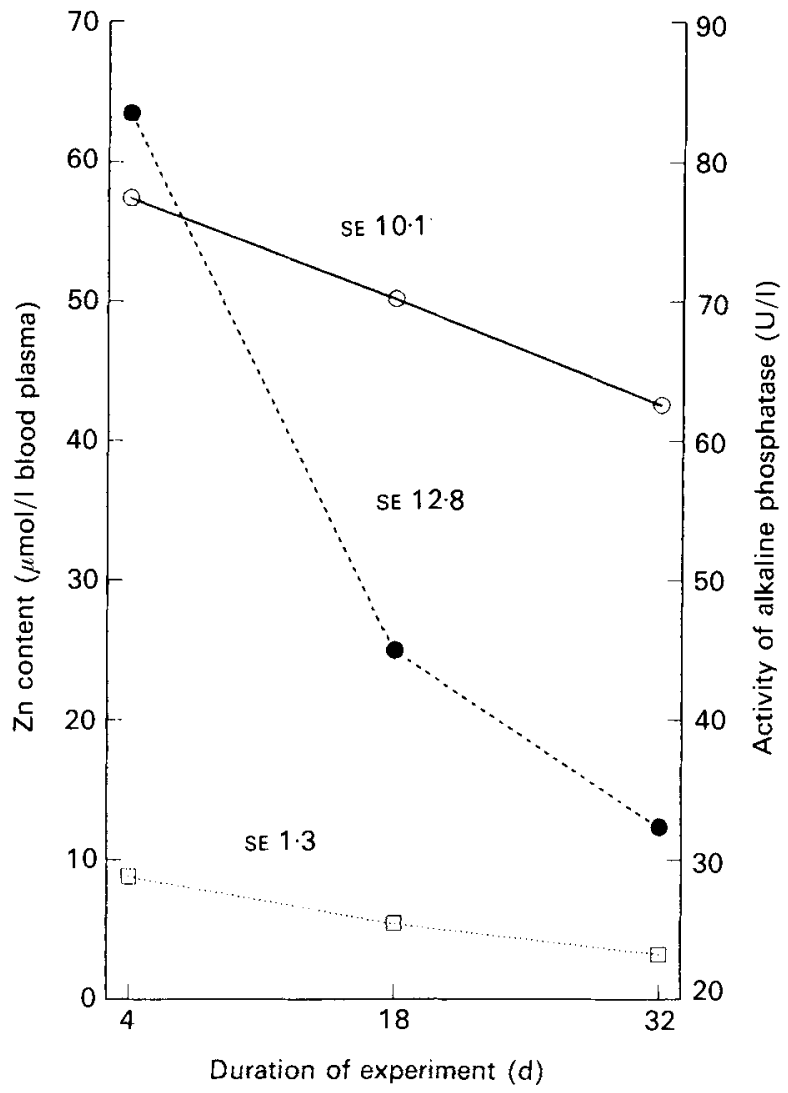

Fig. 1. The effect of the duration of the experiment on zinc status $(\mu \mathrm{mol} / \mathrm{l})$ in whole blood $(O)$ and plasma $(\square)$ and activity of alkaline phosphatase (EC 3.1.3.1) in plasma (O) of pigs fed on rapeseed (Brassica napus L.) containing different levels of calcium, which did not significantly affect the variables measured. Values are averages of all animals, irrespective of diet. SE standard error of analyses, i.e. between time, within litters; df 27. For details of procedures, see pp. 212-214.

$\mathrm{Mg}$. Dietary Ca level did not affect the small intestinal absorption of $\mathrm{Mg}$, which was $1.0 \mathrm{~g} / \mathrm{d}(39 \%$ of intake). Apparent absorption from the total gastrointestinal tract was lower than small intestinal absorption from the non-supplemented diet, but increased with increasing $\mathrm{CaCO}_{3}$ content in the diet $(P<0.001)$. Urinary excretion increased concomitantly; the retention of $\mathrm{Mg}$ was, however, highest at the highest Ca level.

$\mathrm{Fe}, \mathrm{Zn}, \mathrm{Cu}$ and $\mathrm{Mn}$. No significant effect on $\mathrm{Fe}, \mathrm{Zn}, \mathrm{Cu}$ and $\mathrm{Mn}$ absorption of increasing $\mathrm{Ca}$ levels was observed (Table 5). The average small intestinal absorption $(\mathrm{mg} / \mathrm{d}$; percentage absorption in parentheses) of $\mathrm{Fe}, \mathrm{Zn}, \mathrm{Cu}$ and $\mathrm{Mn}$ was $55 \cdot 1$ (42), 13.3 (38), $2 \cdot 3$ (53) and 12.8 (39) respectively. Apparent total intestinal absorption ( $\mathrm{mg} / \mathrm{d}$; percentage absorption in parentheses) was $32.4(25), 5.4(16), 1.5(35), 4.6(14)$ respectively and the retention $(\mathrm{mg} / \mathrm{d})$ of $\mathrm{Fe}, \mathrm{Zn}$ and $\mathrm{Cu}$ was $29 \cdot 1,4 \cdot 7,1 \cdot 2$ respectively. Urinary $\mathrm{Mn}$ excretion was not measured.

\section{Blood measurements}

There was no effect of dietary $\mathrm{Ca}$ level on any of the measured blood variables. Several of the measured blood variables were affected by the duration of treatment (Table 6) The content of $\mathrm{P}$ and $\mathrm{Mg}$ in whole blood and plasma increased with time. $\mathrm{Zn}$ in plasma was 
Table 7. Comparisons between the two total gastrointestinal balances in pigs fed on rapeseed (Brassica napus, L.) diets containing different levels of calcium (days 8-13 and 22-27)

(Values are pooled means of diets for eleven pigs)

\begin{tabular}{lcccc}
\hline$=$ & & & $\begin{array}{c}\text { Statistical } \\
\text { significance } \\
\text { of difference: } P<\end{array}$ \\
Balance... & 1 & 2 & sE* & NS \\
N Absorption:Intake & 0.814 & 0.827 & 0.027 & 0.001 \\
N Urine:Absorption & 0.395 & 0.576 & 0.063 & 0.001 \\
N Retention:Intake & 0.494 & 0.350 & 0.054 & $\mathrm{NS}$ \\
S Absorption:Intake & 0.801 & 0.802 & 0.033 & 0.01 \\
S Urine:Absorption & 0.450 & 0.533 & 0.060 & 0.05 \\
S Retention:Intake & 0.443 & 0.376 & 0.051 & \\
\hline
\end{tabular}

* Standard error of analysis for differences between balances analysed within diets and litters, df 10 .

significantly reduced from $8.8 \mu \mathrm{mol} / 1$ at day 4 to $3.2 \mu \mathrm{mol} / 1$ at day $32(P<0.001)$. The activity of alkaline phosphatase was also significantly reduced $(P<0.001)$ over this period (Fig. 1). Levels of $\mathrm{Ca}, \mathrm{Cu}, \mathrm{Fe}$ and haemoglobin did not change significantly.

\section{Liver $\mathrm{Zn}$ content}

The $\mathrm{Zn}$ content of the livers was, on the average, $90 \mathrm{mg} / \mathrm{kg}$ tissue dry matter with minor but significant effects of diet $(P=0 \cdot 027, \mathrm{sE} 6 \cdot 1)$. Values for diets 1,2 and 3 were $98 \cdot 0,82 \cdot 0$ and $88.7 \mathrm{mg} / \mathrm{kg}$ respectively.

\section{Effect of duration of experiment on $N$ and $S$ retention}

Results from the two intestinal balance periods (days 8-13 and 22-27) are given in Table 7. The absorption of $\mathrm{N}$ was similar in the two periods while the urinary excretion increased in the second balance period, resulting in a reduced retention. The same tendencies were observed for $\mathrm{S}$. No other differences between the balance periods were observed.

\section{DISCUSSION}

Apparent absorption of $\mathrm{S}$ and $\mathrm{N}$ was not affected by the dietary supply of $\mathrm{CaCO}_{3}$, either for ileal or faecal calculations. Urinary $\mathrm{N}$ excretion decreased with increasing $\mathrm{Ca}$ in the diet, resulting in an increasing $\mathrm{N}$ retention (and $\mathrm{S}$ retention). Growth was significantly favoured by the intermediate $\mathrm{Ca}$ level $(7.2 \mathrm{~g} / \mathrm{kg})$, indicating that the intrinsic $\mathrm{Ca}$ level was not sufficient, and that the high level of $\mathrm{Ca}$ depressed growth. The observed $\mathrm{N}$ retention was, thus, not correlated with the overall growth of the animals; we have no completely valid explanation to this apparent contradiction. It could be that the retained $\mathrm{N}$ was incorporated in a relatively heavier bone mass. In addition, comparisons of the two total gastrointestinal balances (Table 7) indicate that protein supply was not the growth-limiting factor. From amino acid analyses of diets (not shown) it is evident that $80 \%$ of dietary $\mathrm{N}$ and $50 \%$ of dietary $\mathrm{S}$ was of amino acid origin. Both elements were retained to a decreasing extent with the duration of the experiment; this also suggests that factors other than protein impaired the potential for growth.

$\mathrm{Ca}$. The observed greater retention of $\mathrm{Ca}$ with increasing dietary $\mathrm{Ca}$ level was not supported by analysis of skeletal bones. $\mathrm{Ca}$ and $\mathrm{Ca}: \mathrm{P}$ values were not significantly changed 
in the bone ash of metacarpahia or fibula (results not shown). Possibly the increased retention of $\mathrm{Ca}$ resulted in a greater total bone mass in these pigs, although this is not obvious from body weight gains. This possiblity would also support the observed increasing retention of $\mathrm{N}$ in the same animals.

$P$. Pierce et al. (1977) studied the availability of intrinsic cereal $P$ and added phytate-P to the growing pig, at different $P$ levels. They concluded that apparent absorption of intrinsic $\mathrm{P}$ is mainly of non-phytate origin, and that availability of phytate-P was below $20 \%$, while added dicalcium phosphate absorption was considerably higher. Pointillart et al. (1987), on the other hand, stated that $P$ availability from an intrinsic source is dependent on the feed phytase level, while intestinal mucosal phosphatase and intestinal alkaline phosphatase activities appeared to be of minor importance for the liberation of phosphate. Similar conclusions have been drawn from studies in human ileostomates (Sandberg et al. 1987; Sandberg \& Andersson, 1988).

The defatted rapeseed used in the present study was heat-treated and, therefore, without phytase activity (Boisen, 1987; A.-S. Sandberg, personal communication). The analysis of the feeds showed a phytate content of approximately $20 \mathrm{mmol} / \mathrm{kg}$, thus about $65 \%$ of total $P$ had to be of phytate origin. This would mean that at least $0.9 \mathrm{~g}$ of the $\mathbf{P}$ apparently absorbed in the small intestine per $\mathrm{d}$ was derived from phytic acid, e.g. $15 \%$ of the phytic acid-P, values in accordance with our direct observations (A.-S. Sandberg, T. Larsen and B. Sandström, unpublished results). Degradation of phytic acid must consequently have taken place, e.g. by the action of micro-organisms or endogenous, more or less specific, enzymes. Both the presence and activity of bacteria in the ileum have been clearly demonstrated in the pig (Borg Jensen, 1987). Separate bacterial phytase capacity in the small intestine has, however, apparently not been investigated.

$\mathrm{Mg}$. Absorption of $\mathrm{Mg}$ in the present study increased with the Ca content of the diet. Small intestinal apparent absorption as well as total intestinal absorption of $\mathrm{Mg}$ was correlated with the absorption of $\mathrm{Ca}(r 0.59, P<0.10)$, and $(r 0.88, P<0.001)$ respectively. This is in clear contrast to statements of Pointillart (1985), who collected data from various experimental studies on pigs. He concluded that $\mathrm{Mg}$ absorption was not affected by dietary Ca. In a study with rats parallel to the present one (T. Larsen and B. Sandström, unpublished results) we observed an identical increase in $\mathrm{Mg}$ absorption and retention as the dietary $\mathrm{Ca}$ level increased. The feed was exactly the same batch of rapeseed meal as was fed to the present pigs. Whether this $\mathrm{Ca}-\mathrm{Mg}$ interaction is due to some unidentified characteristics of the rapeseed meal per se remains to be elucidated.

$\mathrm{Zn}$. Several authors have reported parakeratosis, dermatitis and $\mathrm{Zn}$ deficiency under conditions comparable to those of the present study, i.e. relatively low dietary $\mathrm{Zn}$ and increasing Ca levels (Tucker \& Salmon, 1955; Luecke et al. 1956, 1957; Whiting \& Bezeau, 1958). In the present investigation, the pigs did not show any visible sign of $\mathrm{Zn}$ deficiency throughout the period of $32 \mathrm{~d}$.

Blood $\mathrm{Zn}$ variables indicated that available $\mathrm{Zn}$ may have been inadequate. Dietary $\mathrm{Ca}$ per se apparently did not affect the plasma $\mathrm{Zn}$ concentrations, but duration of experimental feeding lowered the plasma $\mathrm{Zn}$ and the whole-blood $\mathrm{Zn}$. In addition, the activity of alkaline phosphatase, a $\mathrm{Zn}$-containing metallo-enzyme that has been recognized as an index of $\mathrm{Zn}$ status (Luecke et al. 1957; Hoekstra et al. 1967; Agergaard, 1979), fell. The interpretation of this observation should, however, be viewed with caution as several factors together with $\mathrm{Zn}$ status affect the circulating level of this enzyme.

Relative apparent absorption of $\mathrm{Zn}$ over the entire gastrointestinal tract was only $17 \%$ of that ingested. Apparently, the dietary $\mathrm{Ca}$ level did not affect this value. Consequently, the formation of a $\mathrm{Ca}-\mathrm{Zn}$-phytate complex was not obvious, although the $\mathrm{Ca}$ level varied by a factor of three. It is possible that the unavailable $\mathrm{Zn}$ was already complexed in the feed 
in a form not influenced by the added $\mathrm{Ca}$. The phytate: $\mathrm{Zn}$ molar ratio was 50 , which is well above the documented value associated with inhibition of $\mathrm{Zn}$ absorption in the rat (Morris \& Ellis, 1980). In this respect it is also notable that the apparent absorption of $\mathrm{Zn}$ was consistent for the first and second balances. This indicates that the absorbed quantity of $\mathrm{Zn}$ from this type of diet could not be enhanced, even in a state of deficit. Moreover, it is tempting to speculate that the absorbed proportion of the rapeseed meal- $\mathrm{Zn}$ had some specific characteristics, e.g. protein-bound or amino acid-chelated or ligated.

Ileal and faecal comparisons. Comparisons between ileal and faecal disappearances of organic matter, protein (N), S and ash showed that these substances all acted as would be expected; they disappeared to a certain extent in the hind gut. In contrast, all measured minerals in the present study indicated a caecum-colon secretion of mineral.

Net secretion or absorption of $\mathrm{Ca}$ and $\mathrm{P}$ in the caecum-colon portion of the digestive tract has been debated for several decades. In their study Moore \& Tyler (1955a) found increasing concentrations of $\mathrm{Ca}$ and $\mathrm{P}$ in digesta along the caecum-colon intestine, more than could be ascribed entirely to organic matter disappearance. They explain this as a phenomenon of solubility and migration of minerals, faster than dry matter migration as a whole. In a later study, Moore \& Tyler $(1955 b)$ found a high incorporation of radioactive $\mathrm{Ca}$ and $\mathrm{P}$ in caecal and colonic tissue after a single meal. Furthermore, in a parallel study (Moore \& Tyler, 1955b) it was found that colonic digesta, even $4 \mathrm{~d}$ after prolonged feeding contained considerable amounts of labelled $\mathrm{Ca}$ and $\mathrm{P}$. Analysis of consecutive fragments of colon did not, however, indicate concentrations of the markers in the direction of movement.

More recently Partridge (1978) studied net movements of minerals in the gut using pigs cannulated at different locations in the gut. The site of absorption in the small intestine varied for minerals and diets, with movement of minerals along the large intestine being mainly absorptive. However, one diet, a sucrose-starch-groundnut diet, showed an apparent average secretion from the colon of $0.65 \mathrm{~g} \mathrm{Ca} / \mathrm{d}, 1.64 \mathrm{~g} \mathrm{P} / \mathrm{d}(P<0.01)$ and $0 \cdot 11 \mathrm{~g} \mathrm{Mg} / \mathrm{d}$ for $40 \mathrm{~kg}$ pigs. These values as well as the experimental conditions were comparable with those of the present study.

Absorption of $\mathrm{Zn}$ from the stomach has been suggested (Foster et al. 1979), as well as throughout the total length of the small intestine, but only to a limited extent from the colon (Sandström et al. 1986). Endogenous $\mathrm{Zn}$ is secreted into the intestine from pancreatic secretions and through bile (Sullivan et al. 1981), as well as from serosal-to-lumen flux by intestinal cells (Cousins, 1985). To our knowledge, information on secretion of $\mathrm{Zn}$ in the hind gut is not available. Cellular loss and wearing of tissue in the caecum-colon section of the gastrointestinal tract is hardly a satisfying explanation for differences between ileal and faecal disappearances such as that seen in the present investigation. It is more reasonable to assume that some factor associated with the rapeseed diet affected endogenous loss into the lumen of the large intestine, although this factor is not readily identified.

The experimental design, cannulation of the ileum and continuous collection of the digesta for $24 \mathrm{~h}$, possibly, has influenced the magnitude of the balance in the small intestine. Presuming that the collection from the ileum reduced the pressure and the total friction between the digesta and the gut wall, this theoretically would have led to a reduced transit time. This in turn could be expected to result in a reduction in absorption (the opposite of present findings). It is, however, possible that a faster rate of passage could cause modifications in the endogenous secretion of minerals and, thereby, affect the apparent absorption. Another hypothetical possibility could be the presence or absence of a feedback signal from the empty ileo-caecal region to the pancreas, resulting in a reduction of pancreatic juice secretion. The appropriateness of such a mechanism is, however, obscure 
considering the physical distance (15-20 m) and time-period of passage (3-4 h). Taking into account the time-interval between the ileal and faecal samples $(4 \mathrm{~d})$, it is not very likely that total balances could have been affected by the experimental procedure. Furthermore, minerals other than those specifically studied in the present experiment, which were included in the total ash, disappeared to some extent between the ileal cannula and the rectum. This disappearance was not correlated with the $\mathrm{CaCO}_{3}$ content per se. The values were comparable to those presented by Low et al. (1978). In fact the amount disappearing could easily be attributed entirely to absorption of $\mathrm{Na}$ and $\mathrm{K}$, as seen by Patridge (1978).

In conclusion, of the intrinsic minerals in rapeseed meal, $\mathrm{Zn}$ and $\mathrm{Ca}$ were poorly absorbed. The utilization of $\mathrm{Zn}$ was inadequate for maintaining normal circulating levels of $\mathrm{Zn}$ in blood but enough not to affect growth adversely over a 1-month period. Impaired retention of $\mathrm{N}$ during the later stages of the experimental period indicates, however, that some factor other than protein was limiting for optimal growth. Increasing the Ca content of the diet increased $\mathrm{Mg}$ retention, but had no effect on other minerals.

Thus rapeseed meal can contribute significantly to the mineral supply of pigs. For those minerals studied, there was no negative balance. Rapeseed meal, however, will hardly be able to support growth under practical commercial circumstances without additional mineral supplements. A careful evaluation of the actual mineral requirement at different feed formulations might, however, result in a lower requirement for extrinsic minerals, with less negative effects on the environment.

In addition, the present study supports the concept that ileal balances will not reflect the total mineral turnover in animals. The findings of the present investigation, supported by those of other studies, indicates that the caecum-colon region of the gastrointestinal tract may play a significant role in mineral metabolism.

This work was supported by the Danish Research Academy. The authors would like to thank Dr Ann-Sofie Sandberg for management of the phytate analysis; Dr Henry Jørgensen for carrying out surgery; Dorte Hansen and Lone Rasmussen for skilful technical assistance and Dr Bjørn O. Eggum for advice during the course of the work.

\section{REFERENCES}

Agergaard, N. (1979). Alkaline phosphatase in pigs. Studies of alkaline phosphatase isoenzymes in blood and tissues. Thesis. The Royal Veterinary and Agricultural University, Copenhagen, Denmark.

Boisen, S. (1987). Fytinsyre og fytaseaktivitet i foderstoffer. National Institute of Animal Science. Communication no. 675. Foulum DK-8833, Denmark: National Institute of Animal Science.

Borg Jensen, B. (1987). Effect of feed composition on the microbial activity in various segments of the digestive tract of pigs. Proceedings of $38 \mathrm{th}$ Annual Meeting of the European Association for Animal Production, Lisbon, p. 362. Rome: EAAP.

Bowers, G. N. \& McComb, R. B. (1975). Measurement of total alkaline phosphatase activity in human serum. Clinical Chemistry 21, 1988-1995.

Cousins, R. J. (1985). Absorption, transport, and hepatic metabolism of copper and zinc: special reference to metallothionein and ceruloplasmin. Physiological Reviews 65, 238-309.

Davies, N. T., Carswell, A. J. P. \& Mills, C. F. (1985). The effects of variation in dietary calcium intake on the phytate-zinc interaction in rats. In Trace Elements in Man and Animals-TEMA 5, p. 456 [C. F. Mills, I. Bremner and J. K. Chesters, editors]. Farnham Royal: C.A.B. Publications.

Davies, N. T. \& Olpin, S. E. (1979). Studies on the phytate: zinc molar concentrations in diets as a determinant of $\mathrm{Zn}$ availability to young rats. British Journal of Nutrition 41, 591-603.

Fordyce, E. J., Forbes, R. M., Robbins, K. R.\& Erdman, J. W. Jr (1987). Phytate*alcium/zinc molar ratios: are they predictive of zinc bioavailability. Journal of Food Science 52, 440-444.

Foster, D. M., Aamodt, R. L., Henkin, R. I. \& Berman, M. (1979). Zinc metabolism in humans: a kinetic model. American Journal of Physiology 237, R 340 R 349.

Hoekstra, W. G., Faltin, E. C., Lin, C. W., Roberts, H. F. and Grummer, R. H. (1967). Zinc deficiency in reproducing gilts fed a diet high in calcium and its effect on tissue zinc and blood serum alkaline phosphatase. Journal of Animal Science 26, 1348-1357. 
Just, A., Jørgensen, H., Fernandez, J. A., Bech-Andersen, S. \& Enggaard Hansen, N. (1983). The chemical composition, digestibility, energy and protein value of different feedstuffs for pigs. Beretning fra Statens Husdyrbrugsforsog nr. 556. Copenhagen: National Institute for Animal Science.

Low, A. G., Partridge, I. G. \& Sambrook, I. E. (1978). Studies on digestion and absorption in the intestines of growing pigs. 2. Measurements of the flow of dry matter, ash and water. British Journal of Nutrition 39, 515-526.

Luecke, R. W., Hoefer, J. A., Brammel, W. S. \& Schmidt, D. A. (1957). Calcium and zinc in parakeratosis of swine. Journal of Animal Science 16, 3-11.

Leucke, R. W., Hoefer, J. A., Brammel, W. S. \& Thorp, F. Jr (1956). Mineral interrelationship in parakeratosis of swine. Journal of Animal Science 15, 347-351.

Moore, J. H. \& Tyler, C. (1955a). Studies on the intestinal absorption and excretion of calcium and phosphorus in the pig. 1. A critical study of the Bergeim technique for investigating the intestinal absorption and excretion of calcium and phosphorus. British Journal of Nutrition 9, 63-80.

Moore, J. H. \& Tyler, C. (1955b). Studies on the intestinal absorption and excretion of calcium and phosphorus in the pig. 2. The intestinal absorption and excretion of radioactive calcium and phosphorus. British Journal of Nutrition $9,81-93$.

Morris, E. R. \& Ellis, R. (1980). Effect of dietary phytate/zinc molar ratio on growth and bone zine response of rats fed semipurified diets. Journal of Nutrition 110, 1037-1045.

Nes, P. (1979). Routine measurements of total sulphur in biological material. New Zealand Journal of Science 22, 269-272.

Oberleas, D., Muhrer, M. E. \& O'Dell, B. L. (1962). Effects of phytic acid on zinc availability and parakeratosis in swine. Journal of Animal Science 21, 57-61.

O’Dell, B. L. \& Savage, J. E. (1957). Potassium, zinc and distillers dried solubles as supplements to a purified diet. Poultry Science 36, 459460.

O'Dell, B. L. \& Savage, J. E. (1960). Effect of phytic acid on zinc availability. Proceedings of the Society for Experimental Biology and Medicine 103, 304-306.

O'Dell, B. L., Yohe, J. M. \& Savage, J. E. (1964). Zinc availability in the chick as affected by phytate, calcium and ethylenediaminetetraacetate. Poultry Science 43, 415-419.

Partridge, I. G. (1978). Studies on digestion and absorption in the intestines of growing pigs. 3. Net movements of mineral nutrients in the digestive tract. British Journal of Nutrition 39, 527-537.

Pierce, A. B., Doige, C. E., Bell, J. M. \& Owen, B. D. (1977). Availability of phytate phosphorus to the growing pig receiving isonitrogenous diets based on wheat or corn. Canadian Journal of Animal Science 57, 573-583.

Pointillart, A. (1985). Magnesium metabolism in the growing pig. Magnesium Deficiency. First European Congress on Magnesium, Lisbon, pp. 63-65. [M. J. Halpern and J. Durlach, editors]. Basel: Karger.

Pointillart, A., Fourdin, A. \& Fontaine, N. (1987). Importance of cereal phytase activity for phytate phosphorus utilization by growing pigs fed diets containing triticale or corn. Journal of Nutrition 117, 907-913.

Sandberg, A.-S. \& Ahderinne, R. (1986). HPLC method for determination of inositol tri-, tetra-, penta-, and hexaphosphates in foods and intestinal content. Journal of Food Science 51, 547-550.

Sandberg, A.-S. \& Andersson, H. (1988). Effect of dietary phytase on the digestion of phytate in the stomach and small intestine of humans. Journal of Nutrition 118, 469-473.

Sandberg, A.-S., Andersson, H., Carlsson, N.-G. \& Sandström, B. (1987). Degradation products of bran phytate formed during digestion in the human small intestine: effects of extrusion cooking on digestibility. Journal of Nutrition 117, 2061-2065.

Sandström, B., Cederblad, À., Kivisto, B., Stenquist, B. \& Andersson, H. (1986). Retention of zinc and calcium from the human colon. American Journal of Clinical Nutrition 44, 501-504.

SAS Institute Inc. (1985). SAS Users Guide: Statistical Version 5. Cary, N. C.: SAS Institute Inc.

Smith, W. H., Plumlee, M. P. \& Beeson, W. M. (1962). Effect of source of protein on zinc requirement of the growing pig. Journal of Animal Science 21, 399-405.

Stuffins, C. B. (1967). The determination of phosphate and calcium in feeding stuffs. Analyst 92, $107-111$.

Sullivan, J. F., Williams, R. V., Wisecarver, J., Etzel, K., Jetton, M. M. \& Magee, D. F. (1981). The zinc content of bile and pancreatic juice in zinc-deficient swine. Proceedings of the Society for Experimental Biology and Medicine 116, 39-43.

Tucker, H. F. \& Salmon, W. D. (1955). Parakeratosis or zinc deficiency disease in the pig. Proceedings of Society for Experimental Biology and Medicine 88, 613-616.

Whiting, F. \& Bezeau, L. M. (1958). The calcium, phosphorus and zinc balance in pigs as influenced by the weight of pigs and the level of calcium, zinc and vitamin D in the ration. Canadian Journal of Animal Science 38 , 109-117. 